\title{
Optimization of Time and Temperature Gelatin Extraction from Pink Perch (Nemipterus bathybius) Head using Response Surface Methodology (RSM)
}

\author{
Ulfatul Mardiyah ${ }^{1 *}$, Simon Bambang Widjanarko ${ }^{2}$, Kiki Fibrianto ${ }^{2}$ \\ ${ }^{1}$ Department of Agricultural Product Technology, Faculty of Agricultural Technology, University of Brawijaya, Malang, \\ Indonesia \\ ${ }^{2}$ Faculty of Agricultural Technology, University of Brawijaya, Malang, Indonesia
}

\begin{abstract}
Gelatin from fisheries byproducts was very potential to be used as an alternative gelatin substitute for bovine and porcine gelatin. In this study, optimization of pink perch head gelatin extraction was carried out based on temperature and extraction time. Factorial design and Response Surface Methodology (RSM) were used to optimize the gelatin extraction process of pink perch (Nemipterus bathybius) head. The purpose of this research was to determine the optimum condition of the pink perch head extraction process based on the temperature and time of extraction. The extraction temperature $\left(50^{\circ} \mathrm{C}-90^{\circ} \mathrm{C}\right)$, and the extraction time (3-7 hours) were the independent variables. The response variables of this study were the yield of gelatin (\%), gel strength (g.bloom) and viscosity (cP). The optimum extraction conditions were obtained at the extraction temperature of $74.40^{\circ} \mathrm{C}$ for 5.42 hours with a yield of $5.31 \%$, the gel strength of 311.01 g.bloom and the viscosity of $5 \mathrm{cP}$. Considering its similarity to the commercial gelatin, particularly on their chemical characteristics, it can be suggested that the head of pink perch is a potential alternative of gelatin source.
\end{abstract}

Keywords: Extraction, Gelatin, Optimization, Pink Perch Head

\section{INTRODUCTION}

Gelatin is a polypeptide obtained from collagen degradation of animal's bone and skin which functions as an emulsifier, foam-former, gel-former and edible-film [1,2]. Gelatin is generally derived from bone and skin of bovine or porcine. However, the issue of BSE (Bovine Spongiform Encephalopathy) disease and differences in consumer belief is a problem for consuming bovine or porcine gelatin. Therefore, gelatin obtained from the industrial waste of fish processing can be used as an alternative source of gelatin [3].

The fish head is a waste produced by fish in the processing industry. Most of the waste is disposed and used to feed livestock [4]. Considering the chemical components of the fish head, its utilization as a source of gelatin production can effectively increase the value of waste economically and reduce environmental pollution as well [5].

To date, fish gelatin tends to be sub-quality compared to both bovine and porcine gelatin [6]. One of the factors that can affect the physicochemical properties of gelatin is the temperature and time of gelatin extraction.

\footnotetext{
* Correspondence address:

Ulfatul Mardiyah

Email : ulfa11bee@gmail.com

Address : Faculty of Agricultural Technology, Brawijaya University, Indonesia
}

Several studies show that higher temperature and longer time of extraction can increase yield but decrease gel's strength and viscosity $[7,8]$. Therefore, the extraction condition of gelatin production needs optimization. Gelatin extraction with a variation of temperature and time has been reported for clown featherback [9], African catfish [10], seabass [2], wami tilapia [7] and channel catfish [11]. To date, there is few published works reported for gelatin extraction of pink perch head originated from Indonesia. The purpose of this research is to optimize temperature and extraction time of gelatin from pink perch (Nemipterus bathybius) head. Response Surface Methodology (RSM) was to establish an optimum condition of yield, gel strength and viscosity of gelatin. The optimum product then compared with commercial gelatin.

\section{MATERIAL AND METHOD \\ Materials}

The head of the pink perch (Nemipterus bathybius) was obtained from fisherman in the sea of Mimbo, Situbondo, East Java, Indonesia. The fish head was stored at $-25^{\circ} \mathrm{C}$ until it was used. The chemical used are $\mathrm{HCl}(37 \%)$ Pro Analysis (PA).

\section{Preparation of Raw Materials}

Pink perch head separated from the body using a knife. Head washed with flowing tap water to remove dirt on the fish head and drain and then degreased by tumbling it in warm water 
at the temperature of $80^{\circ} \mathrm{C}$ for 20 minutes. Meat separated from the head, and then the pink perch head crushed using a knife to enlarge surface contact area.

\section{Pre-treatment}

Frozen pink perch head was thawed and drained. It was then weighed $100 \mathrm{~g}$ using analytical balance (Denver Instrument $\mathrm{M}-310$ ) and soaked for 48 hours into $2.98 \% \mathrm{HCl}(1: 3 \mathrm{w} / \mathrm{v})$ obtained from the previous study. The mixture was filtered using filter cloth. The collected residue (ossein) was washed by aquadest until reaching neutral $\mathrm{pH}$ and then it was ready for gelatin extraction.

\section{Gelatin Extraction}

The ossein obtained from the pre-treatment process was weighed using analytical balance (Denver Instrument $\mathrm{M}-310$ ) and diluted into distilled water $(1: 3 \mathrm{w} / \mathrm{v})$ and covered with aluminum foil. Sample was extracted using water bath with variation of extraction temperature $\left(41.7,50,70,90,98.3^{\circ} \mathrm{C}\right)$ and extraction time $(2.17,3,5,7,8.22$ hours). The filtrate was filtered using filter cloth and dried inside a cabinet dryer at $50-55^{\circ} \mathrm{C}$ for 48 hours.

Table 1. Experimental Design of Gelatin Extraction

\begin{tabular}{cccccc}
\hline $\begin{array}{c}\text { Independent } \\
\text { Variable }\end{array}$ & \multicolumn{5}{c}{ Range and Level } \\
\cline { 2 - 3 } & $\mathbf{- 1 . 4 1}$ & $\mathbf{- 1}$ & $\mathbf{0}$ & $\mathbf{1}$ & $\mathbf{1 . 4 1}$ \\
\hline $\begin{array}{c}\text { Extraction } \\
\text { temperature } \\
\left({ }^{\circ} \mathrm{C}\right)\left(\mathrm{X}_{1}\right)\end{array}$ & 41.7 & 50 & 70 & 90 & 98.3 \\
$\begin{array}{c}\text { Extraction time } \\
\text { (hour) }\left(\mathrm{X}_{2}\right)\end{array}$ & 2.17 & 3 & 5 & 7 & 8.22 \\
\hline
\end{tabular}

\section{Experimental Design}

Central composite design (CCD) response surface methodology (RSM) was applied to analyze the relationship between independent variables and dependent variables on the gelatin extraction of pink perch head. The independent variables were extraction temperature $\left(\mathrm{X}_{1},{ }^{\circ} \mathrm{C}\right)$ and extraction time ( $\mathrm{X}_{2}$, hour), while the dependent variable was yield $\left(Y_{1}, \%\right)$, gel strength $\left(Y_{2}\right.$, g.bloom) and viscosity $\left(Y_{3}, c P\right)$. The experimental design is shown in Table 2 . Statistically, the results of the central composite design experiments were analyzed with Design Expert 7.1.5. The purpose of optimization of gelatin extraction is to explain the effect of extraction temperature and time on yield, gel strength, and viscosity of gelatin from Pink perch head. Table 2 shows the result of the experiment from 2 factors with 5 levels ofcentral composite design, as the model of response surface method resulted from each response variable is shown on Table 3.

\section{Yield of Gelatin}

The yield was calculated by the ratio of the dry weight of produced gelatin and raw material used in the extraction process. The formula for yield as follows.

$$
\text { Yield }=\frac{\text { dry weight of gelatin }}{\text { weight of raw material }} \times 100 \% .
$$

\section{Determination of Gel Strength}

Gel strength measurement was prepared based on Ratnasari method [13]. Gelatin was dissolved in $60^{\circ} \mathrm{C}$ distilled water to a concentration of $6.67 \%(\mathrm{w} / \mathrm{v})$. The mixture was stirred using magnetic stirrer (type MS200) until the gelatin was completely dissolved. The solution was incubated at $4^{\circ} \mathrm{C}$ for $18 \mathrm{~h}$ before analysis. Gel strength was measured by Tensile Strength Instrument (Imada/ZP-200N) Digital Imaging Model, load cell used $5 \mathrm{~kg}$ and $1 \mathrm{~mm}$ diameter Teflon Plunger Cylinder. The speed of the plunger was $0.5 \mathrm{~mm} . \mathrm{s}^{-1}$. Maximum strength (in grams) was taken at a penetration distance of $4 \mathrm{~mm}$.

Table 2. The Experimental Design and Results for Gelatin Yield, Gel Strength, and Viscosity

\begin{tabular}{|c|c|c|c|c|c|c|c|}
\hline \multirow{2}{*}{ Treatment } & \multicolumn{2}{|c|}{ Code } & \multicolumn{2}{|c|}{ Actual } & \multicolumn{3}{|c|}{ Responses } \\
\hline & $X_{1}$ & $\mathrm{X}_{2}$ & Temperature $\left({ }^{\circ} \mathrm{C}\right)$ & Time(hour) & Yield(\%) & Gel Strength(g.bloom) & Viscosity(cP) \\
\hline 1 & 1.00 & -1.00 & 50 & 3 & 1.01 & 57.78 & 3.33 \\
\hline 2 & 1.00 & -1.00 & 90 & 3 & 6.66 & 88.37 & 3.00 \\
\hline 3 & -1.00 & 1.00 & 50 & 7 & 2.39 & 163.15 & 3.67 \\
\hline 4 & 1.00 & 1.00 & 90 & 7 & 8.10 & 47.59 & 2.67 \\
\hline 5 & -1.414 & 0.00 & 41.70 & 5 & 1.04 & 2.67 & 3.40 \\
\hline 6 & 1.414 & 0.00 & 98.30 & 5 & 8.85 & 0.00 & 2.33 \\
\hline 7 & 0.00 & -1.414 & 70 & 2.17 & 1.95 & 149.56 & 3.33 \\
\hline 8 & 0.00 & 1.414 & 70 & 7.83 & 5.45 & 214.14 & 3.67 \\
\hline 9 & 0.00 & 0.00 & 70 & 5 & 4.52 & 309.31 & 5.33 \\
\hline 10 & 0.00 & 0.00 & 70 & 5 & 5.04 & 302.51 & 4.67 \\
\hline 11 & 0.00 & 0.00 & 70 & 5 & 4.90 & 319.51 & 5.00 \\
\hline 12 & 0.00 & 0.00 & 70 & 5 & 4.81 & 316.11 & 5.67 \\
\hline 13 & 0.00 & 0.00 & 70 & 5 & 4.50 & 305.91 & 4.67 \\
\hline
\end{tabular}


Table 3. Analysis of Variance (ANOVA) for the Response Surface Model of Yield, Gel Strength and Viscosity

\begin{tabular}{|c|c|c|c|c|c|c|}
\hline Responses & Source & $\begin{array}{c}\text { Sum of } \\
\text { Squares }\end{array}$ & df & $\begin{array}{l}\text { Mean } \\
\text { Square }\end{array}$ & F-Value & $\begin{array}{l}\text { p-value } \\
\text { Prob }>F\end{array}$ \\
\hline \multirow{10}{*}{ Yield } & Model & 72.17 & 5 & \multirow{3}{*}{$\begin{array}{l}14.43 \\
62.75\end{array}$} & & \\
\hline & $X_{1}$ & 62.75 & 1 & & 113.09 & $<0.0001$ \\
\hline & $x_{2}$ & 7.54 & 1 & & 491.66 & $<0.0001$ \\
\hline & $x_{1} x_{2}$ & $9.030 \mathrm{E}-004$ & 1 & $\begin{array}{l}7.54 \\
0304\end{array}$ & 59.11 & 0.0001 \\
\hline & $x_{1}^{2}$ & 0.16 & 1 & 9.030E-004 & 7.075E-003 & 0.9353 \\
\hline & $\mathrm{x}_{2}^{2}$ & 1.55 & 1 & 0.16 & 1.24 & 0.3028 \\
\hline & Residual & 0.89 & 7 & 1.55 & 12.16 & 0.0102 \\
\hline & Lack of Fit & 0.67 & 3 & 0.13 & & \\
\hline & Pure Error & 0.23 & 4 & 0.22 & 3.89 & 0.1112 \\
\hline & Total & 73.06 & 12 & 0.057 & & \\
\hline \multirow{10}{*}{ Gel Strength } & Model & $1.912 E+005$ & 5 & \multirow{2}{*}{38245.53} & & \\
\hline & $X_{1}$ & 984.48 & 1 & & 238.29 & $<0.0001$ \\
\hline & $x_{2}$ & 3038.88 & 1 & $\begin{array}{c}984.48 \\
303888\end{array}$ & 6.13 & 0.0424 \\
\hline & $X_{1} X_{2}$ & 5339.96 & 1 & $\begin{array}{l}3038.88 \\
533996\end{array}$ & 18.93 & 0.0033 \\
\hline & $X_{1}^{2}$ & $1.677 \mathrm{E}+005$ & 1 & 3339.96 & 33.27 & 0.0007 \\
\hline & $x_{2}^{2}$ & 29393.57 & 1 & $\begin{array}{c}1.6 / / \mathrm{t}+00 \mathrm{~b} \\
29393.57\end{array}$ & 1044.80 & $<0.0001$ \\
\hline & Residual & 1123.50 & 7 & $\begin{array}{c}29393.5 / \\
160.50\end{array}$ & 183.14 & $<0.0001$ \\
\hline & Lack of Fit & 924.67 & 3 & $\begin{array}{l}160.50 \\
308 ? 2\end{array}$ & & \\
\hline & Pure Error & 198.83 & 4 & 308.22 & 6.20 & 0.0551 \\
\hline & Total & $1.924 \mathrm{E}+005$ & 12 & 49.71 & & \\
\hline \multirow{10}{*}{ Viscosity } & Model & 12.58 & 5 & & & \\
\hline & $X_{1}$ & 1.01 & 1 & 2.52 & 22.44 & $<0.0001$ \\
\hline & $x_{2}$ & 0.030 & 1 & 1.01 & 9.01 & 0.0199 \\
\hline & $x_{1} x_{2}$ & 0.11 & 1 & 0.030 & 0.27 & 0.6203 \\
\hline & $\mathrm{X}_{1}^{2}$ & 8.50 & 1 & 0.11 & 1.00 & 0.3504 \\
\hline & $\mathrm{x}_{2}{ }^{2}$ & 4.32 & 1 & 8.50 & 75.79 & $<0.0001$ \\
\hline & Residual & 0.78 & 7 & 4.32 & 38.50 & 0.0004 \\
\hline & Lack of Fit & 0.032 & 3 & 0.11 & & \\
\hline & Pure Error & 0.75 & 4 & 0.011 & 0.057 & 0.9796 \\
\hline & Total & 13.37 & 12 & 0.19 & & \\
\hline
\end{tabular}

\section{Determination of Viscosity}

Viscosity was determined following the method done by Ratnasari [13]. Gelatin was dissolved in distilled water $(6.67 \% \mathrm{w} / \mathrm{v})$. The solution was heated in a water bath at $60^{\circ} \mathrm{C}$ for 30 minutes. $20 \mathrm{ml}$ of the gelatin solution was tested using Brookfield LVDV-II viscometer (Brookfield Engineering Laboratories Ltd., Middleboro, MA) with a small sample adapter and equipped with the No.1 spindle at $90 \mathrm{rpm}$.

\section{Fourier Transform Infra Red (FTIR)}

Fourier Transform Infrared spectra were determined using FTIR Spectrophotometer $8400 \mathrm{~S} /$ Shimadzu within range of wavelength 400 $-4000 \mathrm{~cm}^{-1}$.

\section{RESULT AND DISCUSSION}

Yield

The yield of gelatin from pink perch head was obtained between $1.01 \%$ until $8.85 \%$. Analysis of variance (ANOVA) on yield suggests that the response following quadratic model as shown by $\mathrm{R}^{2}=0.9878$. The result of Analysis of Variance (ANOVA) (Table 3 ) shows that variables $X_{1}, X_{2}$, and $X_{2}{ }^{2}$ have a significant effect on the response of gelatin yield with $\mathrm{P}<0.0001$ and 0.0102 . There is no interaction between treatment of extraction time and temperature $(P=0.9353)$. The equation below is the response of gelatin's yield with quadratic model:

Yield $=4.75+2.80 \mathrm{X}_{1}+0.97 \mathrm{X}_{2}+0.015 \mathrm{X}_{1} \mathrm{X}_{2}+0.15 \mathrm{X}_{1}^{2}$ $-0.47 \mathrm{X}_{2}^{2}$.

The equation showed that the yield of gelatin increased alongside the increase of extraction temperature and time extraction respectively (Fig. 1). This result also reported on the previous research by using clown featherback [9], browbanded bamboo shark and blacktip shark [14], seabass [2], Atlantic cod, salmon and Atlantic herring [15].

Higher temperature increases kinetic energy required to hydrolyze triple helix bond of collagen which is water insoluble into watersoluble gelatin with $\alpha$ and $\beta$ chain. Lengthening extraction time may increase the energy supply to hydrolyze collagen $[2,15]$.

\section{Gel Strength}

The gel strength of gelatin extracted from Pink perch head was 0.00 g.bloom (gel isn't formed) until 319.51 g.bloom. The chosen model 
in the analysis of variance was a quadratic model because of its significance on the response of gelatin's gel strength, moreover, it had highest value of $R^{2}\left(R^{2}=0.9942\right)$ and insignificant lack of fit $(P=0.0551)$.

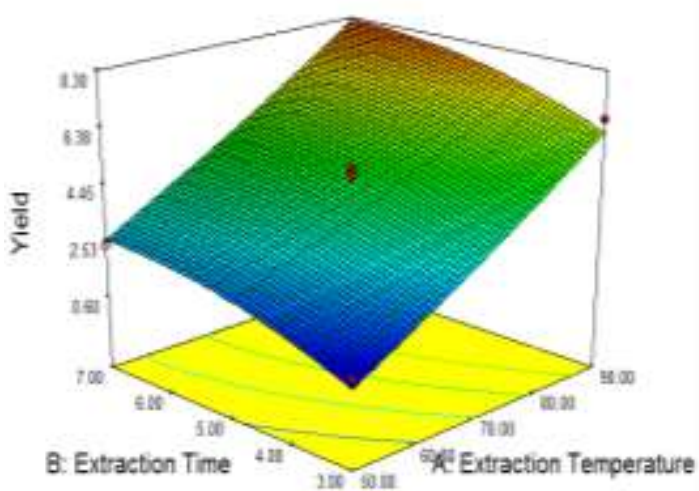

Figure 1. Surface Profile of Yield

The results of analysis of variance (ANOVA) on gel strength with quadratic model shows that variables $X_{1}, X_{2}, X_{1} X_{2}$ significantly affect gelatin's gel strength with $P$-value were $0.0424,0.0033$ and 0.0007 . The value of $X_{1}{ }^{2}$ and $X_{2}{ }^{2}$ also have significant effects with $P<0.0001$ (Table 3 ). The equation of gelatin's gel strength with quadratic model is:

Gel strength $=310.67-11.09 X_{1}+19.49 X_{1} X_{2}-36.54 X_{2}-$ $155.26 X_{1}^{2}-65 X_{2}^{2}$

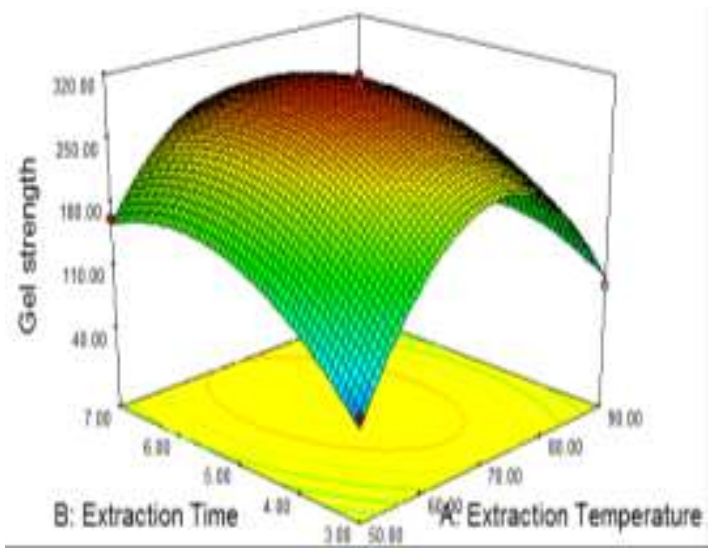

Figure 2. Surface Profile of Gel Strength

The strength of gelatin's gel will decrease with the increase of temperature and time extraction. Low extraction temperature and time also will produce gelatin with low gel strength. High temperature and time of extraction will result in overly degraded protein, thus producing protein fragment with low gel strength properties. Gelatin's molecules with short-chain cannot form strong junction zone, especially hydrogen bonds or weaker bonds such as hydrophobic bond and ionic bond $[9,16]$. Chemically, the formation of gel begins with the formation of Junction Zone within the threedimension network of gelatin chain. Gelatin with low molecular weight will disrupt renaturation of helix bond, renaturation is a recombining process of gelatin strains into helical structure upon cooling. Renaturation is a part of junction zone formation, high molecular weight gelatin with branched structure and non-linier chain can slow down the renaturation process. Gelatin with high molecular weight is suspected of being produced from partial hydrolysis due to a lower temperature and shorter time of extraction. Higher or lower temperature than the optimum condition will weaken the gel strength of gelatin. [17]. The graph of contour plot and surface response profile of gel strength is shown in Figure 2.

\section{Viscosity}

The viscosity of gelatin extracted from pink perch Head was around $2.67 \mathrm{cP}$ until $4.67 \mathrm{cP}$. Analysis of Variance (ANOVA) of viscosity used quadratic model because of high value of $R^{2}=$ 0.8993 and significant model $(P<0.0001)$ with insignificant value of lack of fit ( $P$-value= 0.9796). The result of Analysis of Variance (ANOVA) on the response of gelatin's viscosity shows that quadratically variables $\mathrm{X}_{1}, \mathrm{X}_{1}{ }^{2}, \mathrm{X}_{2}{ }^{2}$ give significant effect on viscosity with each $P$-values as following $0.0199,<0.0001$ and 0.0004 . Variable $X_{2}$ and $X_{1} X_{2}$ have no significant effect on theviscosity of gelatin with the $\mathrm{P}$-value $=0.6203$ and 0.3504 (Table 3). The equation of the response of gelatin's viscosity with quadratic model is:

$\begin{aligned} \text { Viscosity } & =5.07-0.36 \mathrm{X}_{1}+0.0617 \mathrm{X}_{2}+0.17 \mathrm{X}_{1} \mathrm{X}_{2} \\ & -1.11 \mathrm{X}_{1}{ }^{2}-0.79 \mathrm{X}_{2}{ }^{2} \ldots \ldots \ldots \ldots \ldots \ldots \ldots \ldots \ldots \ldots . . . \cdots\end{aligned}$

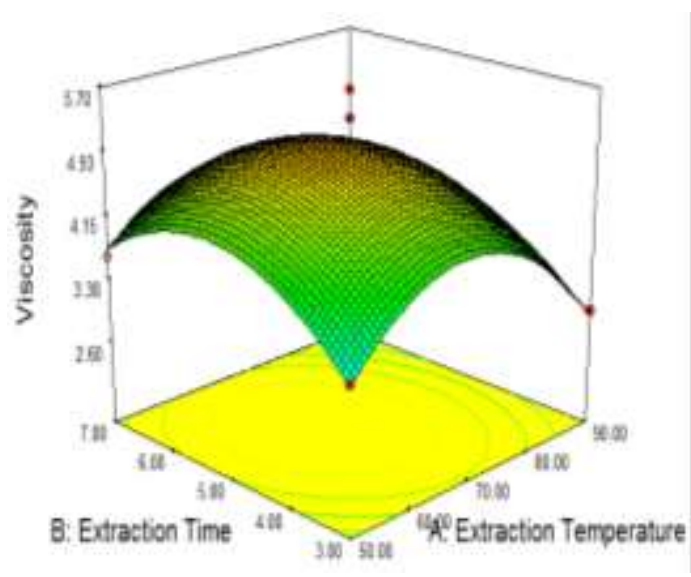

Figure 3. Surface Profile of Viscosity 
The viscosity of the gelatin tends to increase when the temperature and time of extraction increase, but the viscosity will start to decrease back at certain high extraction temperature and time. It has been reported that viscosity of Pink perch's skin and bone are $8.47 \mathrm{cP}$ and, $6.8 \mathrm{cP}$ [18]. Viscosity can be affected by molecular weight and hydrodynamic interaction of intermolecular of open-chain polypeptide $[19,20]$. A low number of the $\beta$ chain in the gelatin molecule caused low viscosity of gelatin from tilapia fish [21]. The graph of contour plot and surface response profile of gelatin's viscosity is shown in Figure 3.

\section{Multiple Response Optimization}

Optimization was done after a mathematic formula had been obtained for each response. The purpose of the optimization was to minimize the required effort and to maximize expected results. From this approach, the optimum condition was stabilized by desirability value. Determination of optimum point criteria is shown in Table 4.

After determining the criteria of optimum conditions, Design Expert program decided optimum solution with the highest value of desirability (approaching 1), only one optimum solution came out which is shown in Table 5 . The next step was the verification of the results of the optimum solution's prediction (Table 5).

The optimum values of the gel strength and viscosity were compared to those of commercial gelatin. Gel strength of gelatin from pink perch was 311.01 g.bloom, while the gel strength of commercial gelatin was 364.54 g.bloom. Based on the result of independent t-test, the gel strength of gelatin from pink perch and commercial gelatin are significantly different with $P$-value $=0.023(P<0.05)$. Statistically, there is no significant difference in viscosity of the pink perch gelatin and commercial gelatin with $\mathrm{P}$ value $=0.059(P>0.05)$.

\section{Fourier Transform Infrared (FTIR)}

The results of functional group characterization using FTIR (Fourier Transform Infra Red) showed specific vibration which was emitted from each functional groups within a certain wavelength. Gelatin from pink perch had similar spectra of FTIR to that of commercial gelatin (e.g Fig.4 and Table 6). Amida A band of gelatin from pink perch was found in the frequency of $3300 \mathrm{~cm}^{-1}$ and commercial gelatin was in the frequency of $3293 \mathrm{~cm}^{-1}$. Amida A band shows there is a stretching vibration of the $\mathrm{N}-\mathrm{H}$ group. Frequency of free $\mathrm{N}-\mathrm{H}$ group is around 3400 - $3440 \mathrm{~cm}^{-1}$ [14]. The frequency will decrease when the $\mathrm{N}-\mathrm{H}$ group is involved with the formation of ahydrogen bond from $\alpha$-chain gelatin with a range of frequency $3289-3304$ $\mathrm{cm}^{-1}[2,23]$.

Amida $B$ band of gelatin from pink perch and commercial gelatin were detected in the frequency of $3080 \mathrm{~cm}^{-1}$ and $3074 \mathrm{~cm}^{-1}$. Amida B band shows stretching vibration of an asymmetric group of $=\mathrm{C}-\mathrm{H}$ and $\mathrm{NH}_{3}{ }^{+}$. Some of the previous research mentioned that Amida $\mathrm{B}$ band was in the frequency of $3071-3079 \mathrm{~cm}^{-1}$ [2] and $3080-3087 \mathrm{~cm}^{-1}$, the low frequency of Amida B band was suspected as a result of interaction between $\mathrm{NH}_{3}{ }^{+}$group with peptide chain [24]. Therefore, the low frequency of the Amida B band from pink perch gelatin is due to the interaction between $\mathrm{NH}_{3}{ }^{+}$group with the peptide chain.

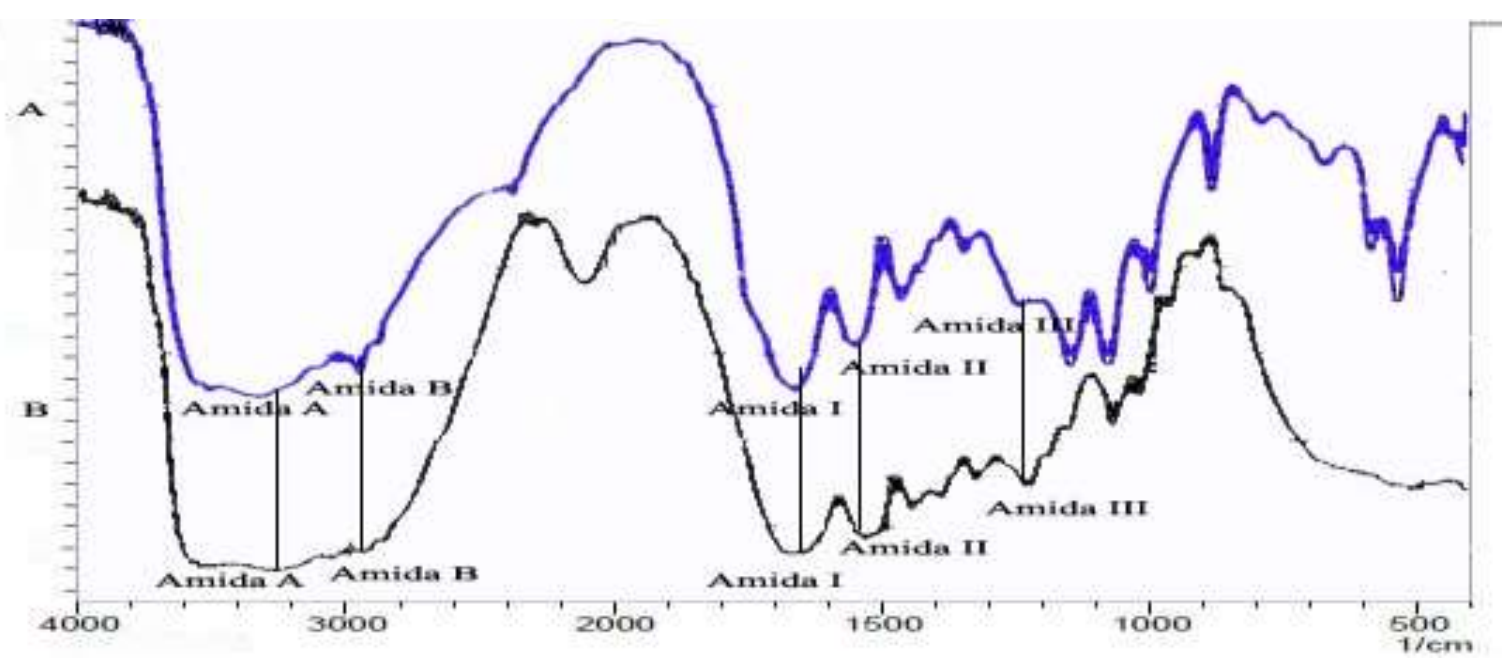

Figure 4. FTIR. A) FTIR spectra of commercial gelatin; B) FTIR spectra of pink perch gelatin 
Table 4. Criteria of Optimum Condition

\begin{tabular}{llcc}
\hline \multicolumn{1}{c}{ Criteria } & Goal & Low & Himit Values \\
\cline { 3 - 4 } & & 41.7 & 98.3 \\
\hline Extraction Temperature $\left({ }^{\circ} \mathrm{C}\right)$ & In range & 2.17 & 7.83 \\
Extraction Time (hours) & In range & 1.01 & 8.85 \\
Yield of Gelatin (\%) & Maximize & 0.00 & 319.51 \\
Gel Strength of Gelatin (g.bloom) & Maximize & 2.33 & 5.67 \\
Viscosity of Gelatin (cP) & Maximize & & \\
\hline
\end{tabular}

Table 5. Optimal condition for Gelatin Extraction from Pink Perch Head

\begin{tabular}{lccccc}
\hline $\begin{array}{c}\text { Condition for } \\
\text { Gelatin } \\
\text { Extraction }\end{array}$ & $\begin{array}{c}\text { Extraction } \\
\text { Temperature } \\
\left.\mathbf{~}^{\circ} \mathbf{C}\right)\end{array}$ & $\begin{array}{c}\text { Extraction } \\
\text { Time } \\
\text { (hours) }\end{array}$ & $\begin{array}{c}\text { Yield } \\
\text { (\%) }\end{array}$ & $\begin{array}{c}\text { Gel Strength } \\
\text { (g.bloom) }\end{array}$ & $\begin{array}{c}\text { Viscosity } \\
\text { (cP) }\end{array}$ \\
\hline $\begin{array}{l}\text { Optimum } \\
\text { Solution }\end{array}$ & 74.40 & 5.42 & 5.56 & 300.21 & 4.91 \\
$\begin{array}{l}\text { Verification } \\
\text { Precision Level }\end{array}$ & 74.40 & 5.42 & 5.31 & 311.01 & 5.00 \\
\hline
\end{tabular}

Table 6. Functional Group of FTIR Spectra

\begin{tabular}{|c|c|c|c|c|}
\hline \multirow{2}{*}{ NO } & \multirow{2}{*}{ Functional Group } & \multicolumn{3}{|c|}{ Frequency } \\
\hline & & Commercial Gelatin & Pink Perch Gelatin & References* \\
\hline 1 & Amida A (N-H Stretching vibration) & $3293 \mathrm{~cm}^{-1}$ & $3300 \mathrm{~cm}^{-1}$ & $3289-3304 \mathrm{~cm}^{-1}$ \\
\hline 2 & $\begin{array}{l}\text { Amida } \mathrm{B}\left(=\mathrm{C}-\mathrm{H} \text { and } \mathrm{NH}_{3}{ }^{+} \text {Asymmetric }\right. \\
\text { Stretching vibration) }\end{array}$ & $3074 \mathrm{~cm}^{-1}$ & $3080 \mathrm{~cm}^{-1}$ & $3071-3087 \mathrm{~cm}^{-1}$ \\
\hline 3 & Amida I ( $C=O$ Stretching vibration) & $1653 \mathrm{~cm}^{-1}$ & $1649 \mathrm{~cm}^{-1}$ & $1632-1653 \mathrm{~cm}^{-1}$ \\
\hline 4 & $\begin{array}{l}\text { Amida II ( } \mathrm{N}-\mathrm{H} \text { Bending and C-N Stretching) } \\
\text { Amida III (C-N stretching and deformation of }\end{array}$ & $1541 \mathrm{~cm}^{-1}$ & $1539 \mathrm{~cm}^{-1}$ & $1540-1543 \mathrm{~cm}^{-1}$ \\
\hline 5 & $\mathrm{~N}-\mathrm{H}$ group) & $1238 \mathrm{~cm}^{-1}$ & $1233 \mathrm{~cm}^{-1}$ & $1233-1239 \mathrm{~cm}^{-1}$ \\
\hline
\end{tabular}

Amida I band of commercial gelatin was found in the frequency of $1653 \mathrm{~cm}^{-1}$, as the one of gelatin from pink perch was in the frequency of $1649 \mathrm{~cm}^{-1}$. Amida I band shows there is stretching vibration of $\mathrm{C}=\mathrm{O}$ group in the secondary structure of the protein [14]. The range of frequency band length of Amida I is $1632-1635 \mathrm{~cm}^{-1}$ [24]. The frequency of Amida I can be affected by the molecular weight of gelatin. A large number of low molecular weight gelatin will make the $\mathrm{C}=\mathrm{O}$ more exposed and more reactive thus the frequency of Amida I band will increase. This happens during high extraction time.

The frequency of Amida II band in commercial gelatin was $1541 \mathrm{~cm}^{-1}$ and the frequency of gelatin from pink perch was $1539 \mathrm{~cm}^{-1}$. Amida II shows bending vibration of the $\mathrm{N}-\mathrm{H}$ group and stretching vibration of $\mathrm{C}-\mathrm{N}$ group. The range of frequency of Amida II band is $1540-1543 \mathrm{~cm}^{-1}$ [2]. Amida III band of commercial gelatin was $1238 \mathrm{~cm}^{-1}$, and the frequency of gelatin from pink perch was $1233 \mathrm{~cm}^{-1}$. The previous research mentioned that Amida III band was in the frequency of $1233-1234 \mathrm{~cm}^{-1}$ [2] and 1237 -
$1239 \mathrm{~cm}^{-1}$ [14]. Amida III band shows a combination of $\mathrm{C}-\mathrm{N}$ and $\mathrm{N}-\mathrm{H}$ vibration stretching movements which are deformed, and it also shows the wagging vibration of $\mathrm{CH}_{2}$ end-chain of glycine and side-chain of proline. Amida III band explains the degradation of triple helixstructure of collagen into gelatin with a much simpler structure $[19,25,26]$.

Aside of Amida band frequency, the peak was found in commercial gelatin with quite high intensity in the frequency $1163 \mathrm{~cm}^{-1}, 1080 \mathrm{~cm}^{-1}$, $1030 \mathrm{~cm}^{-1}$, and $974 \mathrm{~cm}^{-1}$, and the frequency of pink perch gelatin were $1138 \mathrm{~cm}^{-1}, 1067 \mathrm{~cm}^{-1}$, and $988 \mathrm{~cm}^{-1}$. The bands showed stretching vibration of $\mathrm{C}-\mathrm{O}$ group in short peptide chain, and an indication of peptide chain degradation [25, 26].

\section{CONCLUSION}

This study showed that optimum extraction condition from pink perch head was obtained at $74.40^{\circ} \mathrm{C}$ for 5.42 hours. The results of characterization using FTIR (Fourier Transform Infra Red) found specific vibration from Amida A, Amida B, Amida I, II, and III. 


\section{Acknowledgement}

The authors would like to thank the Faculty of Agricultural Technology, University of Brawijaya, Malang, East Java, Indonesia that supported this research.

\section{REFERENCES}

[1] Karim, A.A., R. Bhat. 2009. Fish gelatin: Properties, challenges, and prospects as an alternative to mammalian gelatins. Food Hydrocoll. 23(3). 563-576.

[2] Sinthusamran, S., S. Benjakul, H. Kishimura. 2014. Characteristics and gel properties of gelatin from skin ofseabass (Lates calcarifer) as influenced by Extraction conditions. Food Chem. 152. 276-284.

[3] Kittiphattanabawon, P., S. Benjakul, S. Sinthusamran, H. Kishimura. 2015. Characteristics of collagen from the skin of clown featherback (Chitala ornata). Int. J. Food Sci. Technol. 50. 1972-1978.

[4] Arnesen, J.A., A. Gildberg. 2007. Extraction and characterisation of gelatine from Atlantic Salmon (Salmo salar) skin. Bioresour. Technol. 98(1). 53-57.

[5] Mohtar, N.F., C. Perera, S.Y. Quek. 2010. Optimisation of gelatine extraction from Hoki (Macruronus novaezelandiae) skins and measurement of gel strength and SDS-PAGE. Food Chem. 122(1). 307-313.

[6] Benjakul, S., K. Oungbho, W. Visessanguan, Y. Thiansilakul, S. Roytrakul. 2009. Characteristics of gelatin from the skins of Bigeye Snapper, Priacanthus tayenus and Priacanthus macracanthus. Food Chem. 116(2). 445-451.

[7] da Trindade Alfaro, A., G.G. Fonseca, E. Balbinot, N.E. de Souza, C. Prentice. 2014. Yield, viscosity, and gel strength of Wami Tilapia (Oreochromis urolepis hornorum) skin gelatin: optimization of the extraction process. Food Sci. Biotechnol. 23(3). 765-773.

[8] Wangtueai, S., A. Noomhorm. 2009. Processing optimization and characterization of gelatin from Lizardfish (Saurida spp.) Scales. Food Sci. Technol. 42(4). 825834.

[9] Kittiphattanabawon, P., S. Benjakul, S. Sinthusamran. 2016. Gelatin from clown featherback skin: extraction conditions. Food Sci. Technol. 66. 186-192.

[10] Alfaro, A.T., F.C. Biluca, C. Marquetti, I.B. Tonial, N.E. de Souza. 2014. African catfish (Clarias gariepinus) skin gelatin: extraction optimization and physical-chemical properties. Food Res. Int. 65. 416-422.

[11] Yang, H., Y. Wang, M. Jiang, J.H. Oh, J. Herring, P. Zhou. 2007. 2-Step optimization of the extraction and subsequent physical properties of Channel catfish (Ictalurus punctatus) skin gelatin. Food Chem. Toxicol. 72(4). 188-195.

[12] AOAC. 2000 official methods of analysis, $17^{\text {th }}$ Ed. Association of Official Analytical Chemists. Gaithersberg, MD.

[13] Ratnasari, I., S.S. Yuwono, H. Nusyam, S.B. Widjanarko. 2013. Extraction and characterization of gelatin from different fresh water fishes as alternative sources of gelatin. Int. Food Res. J. 20(6). 3085-3091.

[14] Kittiphattanabawon, P., S. Benjakul, W. Visessanguan, F. Shahidi. 2010. Comparative study on characteristics of gelatin from the skins of Brownbanded Bamboo Shark and Blacktip Shark as affected by extraction conditions. Food Hydrocoll. 24(2-3). 164-171.

[15] Kołodziejska, I.,E. Skierka, M. Sadowska, W. Kołodziejski, C. Niecikowska. 2008. Effect of extracting time and temperature on yield of gelatin from different fish offal. Food Chem. 107(2). 700-706.

[16] Ravey, J., A. Parker, H. Poincare. 2000. Gelation kinetics of gelatin: a master curve and network modeling. Macromolecules. 33. 1063-1071.

[17] Duconseille, A., T. Astruc, N. Quintana, F. Meersman, V. Santé-. 2014. Gelatin structure and composition linked to hard capsule dissolution: a review. Food Hydrocoll. 43. 360-376.

[18] Koli, J.M., S. Basu, B.B. Nayak, S.B. Patange, A.U. Pagarkar, V. Gudipati. 2011. Characteristics of gelatin extracted from skin and bone of Tiger-toothed Croaker (Otolithes ruber) and Pink Perch (Nemipterus japonicus). Food Bioprod. Process. 90(3). 555562.

[19] Muyonga, J.H., C.G.B. Cole, K.G. Duodu. 2004. Extraction and physico-chemical characterization of Nile Perch (Lates niloticus) skin and bone gelatin. Food Hydrocoll. 18. 581-592.

[20] Tabarestani, H.S., Y. Maghsoudlou, A. Motamedzadegan, A.R.S. Mahoonak. 2010. Optimization of physico-chemical properties of gelatin extracted from fish skin of Rainbow Trout (Onchorhynchus mykiss), Bioresour. Technol. 101(15). 6207-6214.

[21] Niu, L., X. Zhou, C. Yuan, Y. Bai, K. Lai, F. Yang. 2013. Characterization of Tilapia 
Optimization of Time and Temperature Gelatin Extraction

(Oreochromis niloticus) Skin gelatin extracted with alkaline and different acid pretreatments. Food Hydrocoll. 33(2). 336341.

[22] Astiana, I., Nurjanah, T. Nurhayati. 2016. Characterization of acid soluble collagen from redbelly yellowtail fusilier fish skin. Jurnal Pengolahan Hasil Perikanan Indonesia. 19. 170-181.

[23] Doyle, B.B., B. Chemistry. 1975. Infrared spectroscopy of collagen and collagen-like polypeptides. Biopolymers. 14. 937-957.

[24] Nagarajan, M., S. Benjakul, T. Prodpran, P. Songtipya. 2012. Characteristics and functional properties of gelatin from Splendid Squid (Loligo formosana) skin as affected by extraction temperatures. Food Hydrocoll. 29(2). 89-397.

[25] Ahmad, M., S. Benjakul. 2011. Food hydrocolloids characteristics of gelatin from the skin of Unicorn Leatherjacket (Aluterus monoceros) as influenced by acid pretreatment and extraction time. Food Hydrocoll. 25(3). 381-388.

[26] Jackson, M., L.P. Choo, P.H. Watson, W.C. Halliday, H.H. Mantsch. 1995. Beware of connective tissue proteins: assignment and implications of collagen absorptions in infrared spectra of human tissues. Biochimica et Biophysic.1. 1-6. 